\title{
ZAKŁADY (DÉPÔTS) DLA EMIGRANTÓW POLSKICH W CHÂTEAUROUX I DEPARTAMENCIE INDRE W LATACH 1831-1833
}

\author{
Jerzy Kuzicki (D) http://orcid.org/0000-0002-3088-8894 \\ Uniwersytet Rzeszowski
}

\section{ABSTRACT \\ REFUGEE DEPOTS FOR POLISH EMIGRANTS IN CHÂTEAUROUX AND INDRE DEPARTMENT IN THE YEARS 1831-1833}

In the article the author presents the setting up and operation of refugee depots (Fr. dépôts) in the Indre department for Polish emigrants who arrived in France after the fall of the November Uprising. The refugee depot in Châteauroux was one of the several depots founded by the French government. It was intended for civil exiles. The other camps for military refugees were set up in Avignon, Lunel, Besançon, Bourges, Lons-le-Saunier, Salins and Dijon. From the beginning of August 1832 till August 1833, the French authorities directed civilians to cities of Indre: Châteauroux - the capital of the department, as well as Issoudun, Levroux, La Chatre, Argenton, Buzançais, Chatillon, Saint Benoit, and La Blanc. The author establishes that in that period of time, 634 Polish refugees went through the camps of the Indre department. Most of them were students (from the Vilnius University), young officials and members of free professions. They came from the pre-partition areas of the former Polish-Lithuanian Commonwealth (Lithuania, Volhynia and Podolia). Despite the restrictive policy of the administration and the fact that they stayed in the French province, the Poles engaged in the social and political life of emigration. They participated actively in democratic and educational organizations of the Great Emigration. In many cases, by their own determination, they went to study and obtained aducation at French universities and technical universities. The article is based on sources from the Indre Department Archives in Chateauroux, archives of the Defense Historical Service in Vincennes, the National Archives in Paris, the Polish Library in Paris, the Princes Czartoryski Library in Krakow, and academic studies.

Keywords: Polish emigration in France, Great Emigration, refugee depots (Fr. dépôts), politics of the French government of Louis Philippe I towards exiles.

Słowa kluczowe: emigracja polska we Francji, Wielka Emigracja, zakłady (fr. dépôts), polityka rządu francuskiego Ludwika Filipa I wobec wychodźstwa. 


\section{UWAGI WSTĘPNE}

Pobyt tułaczy polskich po upadku powstania listopadowego we francuskich zakładach znajdujących się w odległych od Paryża miastach, tak zwanych dépôts, został już zauważony w polskiej historiografii. W pierwszej trzytomowej próbie monografii Wielkiej Emigracji Lubomir Gadon wiele miejsca poświęcił tworzącym się zakładom, ich sytuacji wewnętrznej oraz życiu politycznemu'. Do tej tematyki powrócił Adam Lewak w monumentalnym wydawnictwie Polska, jej dzieje i kultura ${ }^{2}$. Znawca problematyki wychodźstwa polistopadowego, Sławomir Kalembka, w opracowaniu Wielka Emigracja 1831-1863 w obszernym podrozdziale pisał o pierwszych latach pobytu emigrantów we Francji i ich życiu w „,wielkich zakładach”3. Poza tym tematyka zakładów została ujęta $\mathrm{w}$ kolejnych pracach autorstwa między innymi: Leszka Kuka, Roberta Bieleckiego i Janusza Pezdy . Problematyka obecności Polaków $\mathrm{w}$ dépôts dostrzegana była również w historiografii francuskiej, ale pojawiała się przeważnie na marginesie badań nad dziejami wychodźstwa. Można tutaj wymienić opracowania: Jeana-Claude'a Gouya ${ }^{5}$, Gérarda Noiriela ${ }^{6}$, Georges'a Dupeux ${ }^{7}$, Hippolyte'a Corbesa ${ }^{8}$, Patricka Harismendy'ego ${ }^{9}$, Cécile'a Mondonica-Torri ${ }^{10}$. Pomimo tylu opracowań brakuje zbiorczej monografii pobytu Polaków w poszczególnych dépôts. Wyjątek stanowi zakład w Besançon, który stał się tematem opracowań naukowych Eugeniusza Sawrymowicza i Anny Karpińskiej ${ }^{11}$. Niniejszy artykuł ma na celu ukazanie pobytu wychodźców polskich w Châteauroux i innych okolicznych miejscowościach departamentu Indre, gdzie władze francuskie utworzyły zakłady

${ }^{1}$ L. Gadon, Emigracja polska. Pierwsze lata po upadku powstania listopadowego, t. I-III, Kraków 1901-1902, passim.

2 A. Lewak, Czasy Wielkiej Emigracji [w:] Polska, jej dzieje i kultura, t. III, Warszawa 1934, passim.

${ }^{3}$ S. Kalembka, Wielka Emigracja 1831-1863, Toruń 2003, s. 37-56.

${ }^{4}$ L. Kuk, Wielkie zaktady emigracji w latach 1832-1833. Rys historyczno-statystyczny [w:] Rozprawy z dziejów XIX i XX wieku przygotowane dla uczczenia pamięci Profesora Witolda Łukaszewicza, red. S. Kale mbka, Toruń 1978, s. 47; R. Bielecki, Zarys rozproszenia Wielkiej Emigracji we Francji 18311837. Materiały z archiwów francuskich, Warszawa-Lódź 1986, passim; J. Pezda, Ludzie i pieniądze. Finanse w działalności Adama Jerzego Czartoryskiego i jego obozu na emigracji w latach 1831-1848, Kraków 2003, s. 158-170.

5 J-C. Gouy, Les réfugiés polonais au Puy après l'insurrection de 1830, „Cahiers d'Histoire” 1979, no. 3 , s. $78-87$.

${ }^{6}$ G. Noiriel, Le creuset français. Histoire de l'immigration, XIXe-XXe siècles, Paris 1988, passim.

${ }^{7}$ G. Dupeux, Les migrations internationales de la fin du XVIIIe siècle à nos jours, Paris 1980, passim.

${ }^{8}$ H. Corbes, Les émigrés polonais dans les Côtes-du-Nord de 1833 à 1870, „Société d'émulation des Côtes-du-Nord" 1970, s. 80-97.

${ }^{9}$ P. Harismendy, Les réfugiés politiques en Bretagne (1830-1848), „Annales de Bretagne et des Pays de l'Ouest" 2002, t. 109, no. 4, s. 41-58.

${ }^{10}$ C. Mondonico-Torri, Les réfugiés en France sous la monarchie de juillet: l'impossible statut, „Revue d'histoire moderne et contemporaine” 2000, no. 47(4), s. 731-745.

${ }^{11}$ E. Sawrymowicz, $O$,zakładzie” emigracji polistopadowej w Besançon, „Przegląd Humanistyczny”, R. 23, 1979, nr 9, s. 117-126; A. Karpińska, Zakład emigracyjny w Besançon, „Studia i Materiały do Historii Wojskowości" 1985, t. 28, s. 184-197. 
dla cywilnych emigrantów. Centralny obszar Francji stał się tymczasowym miejscem zamieszkania dla kilkuset tułaczy polskich, którzy po upadku listopadowej insurekcji znaleźli się na obczyźnie. Ramy chronologiczne opracowania obejmują okres funkcjonowania zakładów dla Polaków w departamencie Indre.

\section{POWSTANIE WIELKICH ZAKŁADÓW}

Obecność polskich emigrantów we Francji wiązała się między innymi z deklaracją rządu nad Sekwaną. W marcu 1831 roku, przewidując upadek powstania w Królestwie Polskim, ofiarował on nadwiślańskim insuregentom gościnę. Do połowy stycznia 1832 roku Polacy przybywali tutaj indywidualnie. Później zaczęły wkraczać do Francji, głównie przez Alzację i Strasburg oraz przez departament Moselle i Belgię, zorganizowane na wzór wojskowy kolumny liczące nawet kilkaset osób. Także drogą morską z Prus do francuskich portów przybywały transporty z Polakami. Kulminacyjna fala wychodźców dotarła do kraju nad Sekwaną i Loarą między lutym a kwietniem 1832 roku, po czym nastąpił spadek liczby przybyszów. Niemal całkowicie ustał napływ tułaczy w drugiej połowie 1833 roku. Obawiając się destabilizacji wewnętrznej w niespokojnym okresie, zaledwie kilka miesięcy po objęciu rządów przez Ludwika Filipa I postanowiono podporządkować większość Polaków ministerstwu wojny oraz osadzić ich w specjalnych miejscach zakwaterowania dépôts, gdzie mieli przebywać zorganizowani na sposób wojskowy pod kontrolą administracji. Zakłady „wojskowe” funkcjonowały na wzór napoleońskich dépôts de guerre - obozów dla żołnierzy lub jeńców wojennych. Żołnierzy kwaterowano w wojskowych koszarach, oficerowie mogli wynajmować prywatne kwatery ${ }^{12}$. Już 5 listopada 1831 roku minister wojny, marszałek Nicolas Jean de Dieu Soult, wydał podległym sobie władzom rozkaz, aby wszystkich Polaków kierować do Awinionu, głównego miasta departamentu Vaucluse. Tym samym pojawił się pierwszy zakład w dawnej papieskiej stolicy na południu kraju. Równocześnie monarchia Ludwika Filipa godziła się milcząco na istnienie drugiego, nieoficjalnego ośrodka w Paryżu. 22 listopada 1831 roku prezes Rady Ministrów i minister spraw wewnętrznych Casimir Perier podpisał okólnik do prefektów departamentów przygranicznych, wyjaśniając im, że byłych wojskowych polskich należy kierować do Awinionu, cywilów zaś do Châteauroux, głównego miasta departamentu Indre w środkowej Francji. Prefektom zalecano również, aby cywilów zdolnych do służby wojskowej wysyłano również do stolicy departamentu Vaucluse. Ponieważ większość przybyszów walczyła w szeregach armii narodowej, tylko nieliczni w tym okresie udawali się do

${ }^{12} \mathrm{Na}$ temat tzw. wielkich zakładów pisali również: P. Żurawski vel Grajewski, Polskie emigracje 1831-1918 [w:] Historie Polski w XIX wieku, t. IV, red. A. Now ak, Warszawa 2015, s. 121-122; J. Zdrada, Wielka Emigracja po powstaniu listopadowym (seria: „Dzieje Narodu i Państwa Polskiego”, z. III/46), Warszawa 1987, s. 9-10; J. Nowak, Zakłady (dépôts) [w:] Encyklopedia Polskiej Emigracji i Polonii, t. V, red. K. Dopierała, Toruń 2005, s. 376. 
Châteauroux. Niemniej już pod koniec listopada 1831 roku przewidziano, że powstanie punkt zborny „cywilów” właśnie w departamencie Indre ${ }^{13}$. Tworząc wielkie zakłady (dépôts), władze francuskie starały się zrealizować następujące cele: zapewnić sobie kontrolę nad wychodźcami i izolować ich od francuskiego społeczeństwa ${ }^{14}$. Polacy zdążający do Awinionu przechodzili między innymi przez Besançon, główne miasto departamentu Dubs i siedzibę szóstego okręgu wojskowego. Dowódcą tego okręgu był generał Louis Morand, zasłużony napoleończyk, a zarazem osoba związana z krajem nad Wisłą. Żonaty z Polką, Parysówną, przez kilka lat po upadku Napoleona mieszkał w Krakowie. To właśnie polska małżonka wymogła na generale Morandzie interwencję u władz wojskowych i uzyskanie zgody na powstanie następnego zakładu w Besançon, dokąd zaczęto od 7 lutego 1832 roku wysyłać Polaków ze Strasburga i Colmaru. W drugiej połowie tego miesiąca i w marcu dzielono już tułaczy po połowie między Besançon i Awinion ${ }^{15}$. Polacy podlegali restrykcyjnemu prawu. Regulowała to ustawa z 21 kwietnia 1832 roku poddająca emigrantów prawom wyjątkowym, które sankcjonowały usunięcie $\mathrm{z}$ obszaru Francji uciążliwych wygnańców. Przynależność do zakładu dawała zarówno cywilnym, jak i wojskowym tułaczom względną swobodę poruszania się, ograniczoną do wskazanej przez władze miejscowości. W małych ośrodkach trudno było znaleźć pracę dającą zarobek, niezbędny wobec głodowych zasiłków rządowych ${ }^{16}$.

Poczynając od kwietnia 1832 roku, ze względu na przepełnienie zakładu w Besançon zaczęto wysyłać wychodźców polskich z nadgranicznych miejscowości do Lons-le-Saunier, głównego miasta departamentu Jura, od 6 kwietnia również do nieodległego Salins. Od 8 kwietnia 1832 roku Polaków transportowano do Bourges, stolicy departamentu Cher w środkowej Francji. Jeszcze wcześniej - pod koniec lutego 1832 roku - minister wojny, po uwzględnieniu prośby władz municypalnych w Awinionie, postanowił przenieść część tułaczy do miasteczka Lunel w departamencie Hérault. Od drugiej połowy kwietnia aż do końca 1832 roku oraz w pierwszych miesiącach następnego roku nowych tułaczy kierowano głównie do Bourges, nielicznych zaś do Besançon. Zakład w Lunel istniał tylko kilka miesięcy, ponieważ emigranci nie byli zadowoleni z pobytu $\mathrm{w}$ tym sennym miasteczku, niepokoiła ich zwłaszcza możliwość wysyłki do Algierii. W czerwcu 1832 roku zwrócili się oni z prośbą do następcy tronu, księcia Orleanu, o przeniesienie w inne miejsce. W ślad za tym już w początkach września wygnańców polskich skierowano do Le Puy, głównego miasta departamentu Haute-Loire w górach Owerni. W ciągu 1832 roku liczba polskich emigrantów we Francji przekroczyła $4000^{17}$.

${ }^{13}$ R. Bielecki, Zarys rozproszenia..., s. 7-9.

${ }^{14}$ L. Kuk, op. cit., s. 47.

${ }_{15}$ R. Bielecki, Zarys rozproszenia..., s. 24-26; C. Mondonico-Torri, op. cit., s. 731, 735-736, 739.

${ }^{16}$ D. Rederow a, Polski emigracyjny ośrodek naukowy we Francji w latach 1831-1872, WrocławWarszawa-Kraków-Gdańsk 1972, s. 24.

${ }^{17}$ R. Bielecki, Zarys rozproszenia..., s. 24-26; A. Owsińska, La politique du gouvernement fraçais vis-à-vis des Polonais et de la Question polonaise durant les années 1832-1835 [w:] Pologne. L'Insurrection de 1830-1831, sa réception en Europe, textes réunis par D. Beauvois, Lille-Wrocław 


\section{POWSTANIE I LICZEBNOŚĆ ZAKŁADÓW W CHÂTEAUROUX ORAZ DEPARTAMENCIE INDRE}

30 listopada 1831 roku wyszły ostateczne ustalenia: Awinion dla wojskowych, a Châteauroux, Bordeaux lub inne miasta prowincjonalne dla cywilów. Zakład w Châteauroux podlegał Ministerstwu Spraw Wewnętrznych, którym kierowało w tym okresie kilku ministrów. Najpierw Camille Bachasson de Montalivet, następnie zaś Casimir Perier, Adolphe Thiers i Antoine Maurice Apollinaire d'Argout. Zakład tworzył się powoli i do wiosny 1832 roku przybyło tam niewielu powstańców ${ }^{18}$. W tym czasie władze wojskowe zaczęły porządkować istniejące zakłady. Kontroli podlegały stopnie wojskowe emigrantów. Ustalano, kto jest zawodowym wojskowym, a kto przystąpił do powstania, porzucając naukę czy zawody cywilne. Większość ochotników walczących w oddziałach partyzanckich na Litwie czy Ukrainie uznano za cywilów, mimo że władze powstańcze nadały im stopnie wojskowe. Z Awinionu, Besançon i Bourges kierowano ich do Châteauroux, wyłączając ich tym samym spod kurateli Ministra Wojny ${ }^{19}$.

Châteauroux położone nad rzeką Indre w czasie rewolucji stało się siedzibą departamentu, co odbiło się niekorzystnie na rozwoju okolicznych miast: Issoudun, Levroux, La Châtre, Argenton. Polacy w departamencie Indre podlegali władzy miejscowego prefekta. W latach 1830-1835 funkcję tę pełnił Marc-Alexandre-Numa Meinadier (1798-1867). To właśnie jemu podporządkowani byli merowie okolicznych miast (np. merem Argenton był w latach 1830-1838 Jean-Baptiste Rostain, zaś merem Issoudun w latach 1829-1832 Jean Thabaud-Linetière), którzy ze swej strony kontrolowali tułaczy znad Wisły. Ich sprawowaniu bacznie przyglądali się również miejscowi komendanci żandarmerii ${ }^{20}$. Châteauroux znane było z manufaktur sukienniczych i siedziby garnizonu wojskowego. Wśród zakładów przędzalniczych wyróżniała się fabryka Chateaudu Parc pana Mureta de Borda, produkująca tkaniny dla zamożnych mieszkańców oraz wojska i rzemieślników. Dzięki rozwojowi handlu i przemysłu wygląd miasta, w czasie gdy przybyli tam polscy emigranci, znacznie się zmienił. Wówczas rozpoczęto budowę dróg i infrastruktury miejskiej (prace ukończono w 1847 r.). Powstawały nowe budynki, ulice brukowano i poszerzono.

1982, s. 115-119; C. Mondonico-Torri, op. cit., p. 731, oblicza, że w okresie monarchii lipcowej na 20000 emigrantów we Francji było 6000-7000 Polaków.

${ }_{18}$ Archiwum Ministerstwa Obrony Francji w Vincennes (Service Historique de l'Armée de Terre, dalej: SHAT) XL 47, Réfugiés polonais: affaires générales (1832-1844), Ministère de l'Intérieur au le Ministèrede la Guerre, Paris, 23 IX 1831; L. Kuk, op. cit., s. 47-48.

${ }^{19}$ R. Bielecki, Zarys rozproszenia..., s. 27-28. W zakładzie Besançon odrębną grupę, blisko 40-osobową, stanowili oficerowie-ochotnicy z powstania na Litwie, Wołyniu i Podolu. Wraz z blisko 100 ochotnikami podchorążymi tworzyli zwartą i solidarną wspólnotę. Cześć z nich opuściła wkrótce besansoński dépôt i udała się do zakładów dla cywilów departamentu Indre. Zob. A. Karpińska, Zakład emigracyjny..., s. 185.

${ }^{20}$ Pierre-Henry, Histoire des préfets. Cent cinquante ans d'administration provinciale 1800 1850, Paris 1950, s. 149; Biographie des hommes du jour industriels, conseillers-d'État ..., t. V, p. II, par G. Sarrut, B. Saint-Edme, Paris 1853, s. 96. 
Powoli przezwyciężano apatię egzystencji i rutynę mieszkańców Châteauroux. Dobrze zachowany był stary zamek, który wraz z fortyfikacjami dominował nad miastem. W centrum poza budynkiem prefektury znajdowały się teatr i dwa kościoły. W tym czasie Châteauroux liczyło od 11000 do 13000 mieszkańców, a cały departament - około $253000^{21}$. Zdaniem Lubomira Gadona Châteauroux prezentowało się wówczas jako „mieścina licha, nudna, smutna, bez resursów dla tułaczy, nie nęciła ich, toteż się do niej nie kwapili"'22.

W polskiej historiografii utarło się pojęcie dépôt $\mathrm{w}$ Châteauroux, które kieruje uwagę na stolicę departamentu Indre (czasem zwano go zakładem departamentu Indre). Zapomina się, że późnym latem i jesienią 1832 roku byłych powstańców wysyłano do kilku mniejszych i większych miast i miasteczek departamentu. Poza Châteauroux znajdowali się oni w Issoudun, Levroux, La Châtre, Argenton, Buzançais, Châtillon, Saint Benoit, La Blanc. Miasta te były wówczas nieco zaniedbane, chociaż szczyciły się historią sięgającą czasów rzymskich. Największe z nich, Issoudun, liczyło około 1200 osób. W przeszłości znajdował się tam sąd królewski, któremu podlegała połowa regionu Bas-Berry. La Châtre, położone na wzgórzu, na lewym brzegu rzeki Indre, było trzecim pod względem wielkości miastem departamentu (ponad 5000 mieszkańców). W La Blanc (5300 mieszkańców) mieściła się siedziba podprefekta i okręgu (fr. arrondissement). Malowniczo położone miasto dzieliła rzeka Creuse. Wówczas te dwie części łączyła komunikacja promowa, później zbudowano most. Populacja miasteczka Levroux wzrosła z 2600 w 1790 roku do 4014 w 1831 roku. Ośrodek znany był z kultu św. Sylwana oraz licznych garbarni skór i rolnictwa. Ponad 4000 osób mieszkało w Argenton, które słynęło z handlu płótnem oraz miejscowych cegielni ${ }^{23}$.

Wśród historyków istnieją rozbieżności co do liczby emigrantów polskich zamieszkałych w zakładzie Châteauroux i okolicznych miastach. Przebywający w regionie centralnym Polacy pisali w czerwcu 1833 roku w „Pielgrzymie Polskim” następująco: „Wychodźcy polscy zamieszkali w departamencie de l'Indre w liczbie pięciuset, pozbawieni są pomocy lekarskiej, któryby najkorzystniej niesiona być mogła przez rodaków"24. Michał Sokolnicki uważał, że w kwietniu 1832 roku liczba emigrantów w Châteauroux i Besançon dochodziła do 1000 mężczyzn. Zupełnie nieprawdopodobnie wygląda określanie przez tego autora maksymalnej liczby emigrantów w Châteauroux na 1300 osób, co wydaje się zawyżoną liczbą ${ }^{25}$. Lubomir Gadon

${ }^{21}$ Fauconneau-Dufresne, Histoire de Déols et de Chateauroux par le Dr..., Chateauroux 1878, s. 584-585; Histoire des villes de France avec une introduction generale pour chaque Artstide Guilbert..., t. IV, Paris 1845, s. 214-223.

${ }^{22}$ L. Gadon, op. cit., t. III, Kraków 1902, s. 202.

${ }^{23}$ P. Réchaussat, Histoire et légendes de Levroux par..., Chateauroux 1923, s. 67-69, 241-247; Histoire des villes..., t. IV, s. 206-213.

24 „Pielgrzym Polski. Pismo Polityczne i Literackie”, IV-VI 1833, półarkusz 11, cz. 1, s. 44.

${ }_{25}$ M. Sokolnicki, Les origines de l'émigration polonaise en France 1831-1832, Paris 1910, s. 167-168. Podobne dane przytacza Ewelina Tarkowska w opracowaniu o emigrantach polskich w departamencie Côtes-du-Nord. Według tej autorki początkowo zakład w Châteauroux liczył ok. 500 osób, a później liczba ta wzrosła do ok. 1200. Zob. E. Tarkowska, $W$ drodze do departamentu Côtes-du-Nord, „Meritum” 2016, t. VIII, s. 150. 
określił liczbę Polaków w departamencie Indre w lutym 1833 roku na 562 osoby ${ }^{26}$. Sławomir Kalembka oceniał, że w Châteauroux zebrało się około 500 ochotników $\mathrm{z}$ powstania litewskiego. Znalazło się tam w sumie 105 studentów z uniwersytetu wileńskiego i 8 z innych uniwersytetów. Jak sądził ten historyk, w sierpniu 1833 roku, kiedy rozwiązano zakład cywilny departamentu Indre, liczył on ponad 620 wychodźców (w mieście pozostało około 70 osób) ${ }^{27}$. Uczeń profesora S. Kalembki, Leszek Kuk, ustalił, że zakład w Châteauroux zapełniał się bardzo wolno i od lutego do czerwca 1832 roku przyjechało tam około 30 osób. Według tego badacza, który zastrzegał, że jego dane stanów liczbowych nie są wolne od uproszczeń, zakład w Châteauroux i innych mniejszych miejscowościach departamentu liczył w styczniu 1832 roku 2 osoby, w lutym -5 , w marcu -6 , w kwietniu -11 , w maju - 14, a w czerwcu -27. Duży wzrost liczby emigrantów nastąpił latem i w następnych miesiącach, w lipcu odnotowano 82 osoby, w sierpniu - 305, we wrześniu - 367, w październiku - 429, w listopadzie - 487, w grudniu - 519. L. Kuk podał, że początek 1833 roku nie oznaczał wzrostu liczby polskich tułaczy, w departamencie Indre w styczniu tego roku było ich 553, a w kwietniu 1833 roku - 522. Według tego badacza w sierpniu, w momencie rozwiązania zakładu, przebywało w nim 625 emigrantów, a we wrześniu pozostało tam zaledwie 67 osób $^{28}$. Robert Bielecki przyjął, że latem 1832 roku w departamencie Indre znalazła się duża liczba studentów uniwersytetów z ziem polskich. W sierpniu 1832 roku do Châteauroux skierowano 159 studentów i wykładowców z Uniwersytetu Wileńskiego oraz ziemian i urzędników z terenu Litwy, którzy przybyli do Bordeaux na statku „La Vigillante”. Tych emigrantów rozdzielono na mniejsze grupy: 77 z nich wysłano do Issoudun, 30 do La Châtre, a 25 do Buzançais. Jak słusznie zauważył R. Bielecki, Châteauroux to pierwszy zakład, z którego już jesienią 1832 roku przeniesiono tułaczy do kilku mniejszych miejscowości departamentu. Według stanu z 12 listopada 1832 roku w Châteauroux znajdowało się 158 Polaków, w Issoudun - 89, w Levroux - 66, w La Châtre - 34, w Argenton - 26, w Buzançais -25 , w Châtillon -20 , a w La Blanc -5 . Łącznie więc w całym departamencie Indre znalazło się 423 polskich tułaczy ${ }^{29}$. Wspomniany badacz w aneksie cytowanej pracy zamieścił spis 539 osób, które w sierpniu 1833 roku przebywały w poszczególnych zakładach departamentu Indre ${ }^{30}$. Opierając się na powyższych ustaleniach oraz

${ }^{26}$ L. Gadon, op. cit., t. III, s. 207.

${ }_{27}$ S. Kalembka, Wielka Emigracja..., s. 46-47. Na początku roku akademickiego 1830/1831 na Uniwersytet Wileński było zapisanych 1200 studentów oraz ok. 200 dowolnie pobierających naukę z różnych przedmiotów. Ze studentów uniwersytetu, którzy opuścili Wilno, powstał Legion Akademicki. Zasadniczy trzon formacji, dowodzonej przez Gronostajskiego, ks. Dominika Petrellewicza, Janowskiego i Klimaszewskiego, tworzyła grupa 400 akademików oraz profesorów, którzy opuścili Wilno w nocy z 29 na 30 kwietnia 1831 r. Legion Akademicki stoczył kilka potyczek na brzegach Wilii. Ścigany przez Rosjan połączył się z oddziałem partyzanckim Wincentego Matuszewicza na terenie powiatu trockiego. 27 maja 1831 r. w krwawej bitwie z oddziałami rosyjskimi w okolicach Rudnik i Olkiennik poległo ponad 200 akademików. Zob. więcej: J. Feduszka, Powstanie listopadowe na Litwie i Żmudzi, „Teka Komitetu Historycznego Oddziału Lubelskiego PAN" 2004, z. 1, s. 110-160.

${ }^{28}$ L. Kuk, op. cit., s. 48, 52-53.

${ }^{29}$ R. Bielecki, Zarys rozproszenia ..., s. 28.

${ }^{30}$ Ibidem, s. 157-175. 
kwerendzie źródłowej różnych spisów emigrantów w archiwum departamentu Indre w Châteauroux, udało mi się ustalić, że w latach 1831-1833 przez tamtejsze zakłady przewinęło się 634 osoby $^{31}$.

\section{STRUKTURA WIEKOWA, ZAWODOWA I POCHODZENIE TERYTORIALNE}

Na podstawie niepełnych spisów urzędników francuskich można stwierdzić, że średnia wieku emigrantów polskich mieszkających w latach 1831-1833 w departamencie Indre wynosiła 26 lat, najmłodszy miał 17, a najstarszy 51 lat. Jeżeli chodzi o profesję, ustalono ją dla 371 osób z interesujących nas dépôts. $\mathrm{Z}$ dużym prawdopodobieństwem należy przyjąć, że około połowę Polaków, którzy przebywali w Châteauroux i okolicznych zakładach, stanowili studenci (276 studentów oraz 10 uczniów liceów i gimnazjów). Najwięcej było studentów Uniwersytetu Wileńskiego, którzy zaczęli edukację przed wybuchem powstania listopadowego, podejmując między innymi studia medyczne, prawnicze i techniczne. We wspomnianych dépôts znalazło się też sporo byłych urzędników różnych instytucji Królestwa Polskiego (ok. 40 osób) ${ }^{32}$. Mieszkało tam również 6 księży-kapelanów i 3 studentów seminariów duchownych ${ }^{33}$. Wśród wychodźców znalazło się 7 profesorów Uniwersytetu Wileńskiego oraz nauczycieli licealnych. W spisach odnotowano 3 lekarzy i chirurgów, 5 aptekarzy, 8 reprezentantów zawodów prawniczych. Inne profesje emigrantów to: inspektor (4 osoby), geometra (4), leśnik (3) i inżynier (2). Większość $\mathrm{z}$ wymienionych wyżej osób miała stopnie wojskowe. Ponad 300 z nich posiadało

${ }^{31}$ Archives départementales de l'Indre, Châteauroux (dalej: ADCh), M 3293, Administration générale, 1832, Département de l'Indre. Contrôle des Polonais. Réfugiés envoyés en résidence dans ce departement; Liste des passagers Polonais arrivés en rivierre de Bordeaux sur le naviere Prussien la Vigilante mouillé en rade de Pauillac le 11 auot 1832. Movité à Bordeaux les passagers débarqués et remis à la disposition du département de la guerre le...; ADCh, M 3296, Département de l'Indre. Etat nominatif des Réfugiés Polonais en résidence dans la Ville de Levroux; Département de l’Indre. Etat nominatif des Réfugiés Polonais en résidence dans la Ville de Issoudun; Département de l'Indre. Etat nominatif des Réfugiés Polonais en résidence dans la Ville de St. Benoit; ADCh, M 3342, Administration générale, Châteauroux. Etat nominatif des Réfugiés Polonais; Biblioteka Czartoryskich w Krakowie (dalej: BCz), rkps 562, k. 105-110, Spisy emigrantów polskich. Spisy emigrantów polskich w poszczególnych zakładach.

32 Obliczenia własne na podstawie spisów emigrantów w departamencie Indre: ADCh, M 3293, Administration générale, 1832, Département de l'Indre. Contrôle des Polonais. Réfugiés envoyés en résidence dans ce departement; ADCh, M 3296, Réfugiés polonais, listes nominatives des réfugiés résidant dans divers centres de l'Indre (Argenton, La Balanc, Châteauroux...), 1833. Zob. także: BCz, rkps 562, k. 105-110, Spisy emigrantów polskich. Spisy emigrantów polskich w poszczególnych zakładach.

${ }_{33}$ J. Kuzicki, Nieść wiarę i nadzieję na obcej ziemi. Polskie duchowieństwo katolickie w życiu religijnym i polityczno-społecznym Wielkiej Emigracji we Francji (1831-1863), Rzeszów 2014, passim; idem, Duchowni - uczestnicy powstania listopadowego $w$ tzw. wielkich zakładach (dépôts) we Francji w latach 1831-1833 [w:] Wschodnie i zachodnie szlaki migracji Polaków. Ślady działalności kulturalnej, red. P. Kraszewski, M. Lachowicz, T. Nakoneczny, Poznań 2017, s. 46-53. 
stopnie oficerskie, a ponad 130 - stopnie podoficerskie, tylko 10 było szeregowymi żołnierzami ${ }^{34}$.

Pochodzenie terytorialne ustaliłem dla grupy 479 wygnańców z zakładów departamentu Indre. Z materiału źródłowego wynika, że z Ziem Zabranych pochodziło 331 osób. Z tego 270 wywodziło się z przedrozbiorowych terenów litewskich, 46 z ziem południowo-wschodnich dawnej Rzeczypospolitej (głównie z Wołynia i Podola - odpowiednio 21 i 13) oraz 15 osób z okolic Białegostoku włączonego do Cesarstwa Rosyjskiego. Najliczniej tułacze reprezentowali obszar dawnej Litwy, włączonej do Rosji, i tak z guberni wileńskiej pochodziło 190 osób, z guberni grodzieńskiej - 48, z guberni mińskiej - 24, a reszta ze Żmudzi i Kurlandii ${ }^{35}$. Z Królestwa Polskiego wywodziło się 124 tułaczy. Zwraca uwagę fakt, że aż 28 Polaków pochodziło z województwa mazowieckiego (głównie z Warszawy), 23 z województwa sandomierskiego, $17 \mathrm{z}$ płockiego, $15 \mathrm{z}$ augustowskiego, $14 \mathrm{z}$ lubelskiego, $13 \mathrm{z}$ kaliskiego, 9 z krakowskiego, 5 z podlaskiego. Oprócz nich było 9 emigrantów z Wolnego Miasta Krakowa, 8 z Galicji i 7 z Wielkiego Księstwa Poznańskiego ${ }^{36}$. Według spisów francuskich w latach 1831-1833 w Châteauroux znajdowało się 342 Polaków, w Issoudun - 107, w Levroux ze wsią Thoreau - 76, w La Châtre - 25, w Argenton - 27, w Buzançais - 27, w Châtillon - 21, w La Blanc - 5 (dla 4 osób brak danych). Łącznie przez departament Indre w latach 1831-1833 przewinęło się więc 634 polskich tułaczy ${ }^{37}$.

Większość tułaczy polskich, o czym wspomniano, przybyła do Francji drogą lądową przez kraje niemieckie, część drogą morską na statkach „La Vigilante” (164 osoby) i „Lachs” (32 osoby) ${ }^{38}$. Do zakładu w Châteauroux i okolicznych 8 miejscowości zostali skierowani po rejestracji z ośrodków nadgranicznych lub zakładów

${ }_{34}$ Obliczenia własne na podstawie danych źródłowych, zob. przyp. 31 i 32.

${ }^{35}$ Pod pojęciem Litwy emigranci polistopadowi rozumieli terytorium historyczne wchodzące w skład dawnego Wielkiego Księstwa Litewskiego, złączonego z Rzeczpospolitą od czasu unii lubelskiej w 1569 r. Obejmowało ono Litwę i Białoruś. Składało się z następujących województw: wileńskiego, trockiego, nowogródzkiego, brzeskiego i mińskiego, oraz z księstwa żmudzkiego. Zasadniczo Litwa w wyniku trzech rozbiorów prawie w całości została zagarnięta przez Rosję, tylko zachodni skrawek przyjęły Prusy. W ramach państwa rosyjskiego Litwę podzielono na sześć guberni: wileńską, grodzieńską, kowieńską, mińską, mohylewską, witebską. Zwana była Krajem Północno-Zachodnim (także Guberniami Północno-Zachodnimi lub Krajem Zabranym). Zob. J. Feduszka, op. cit., s. 112-113.

${ }^{36}$ Nieco inne liczby podaje sporządzony przez władze francuskie spis: Wolne Miasto Kraków - 17, Wielkie Księstwo Poznańskie - 7, Galicja - 4, razem - 28, ale - jak można zauważyć - ujęto tam miejscowości znajdujące się w Wolnym Mieście Krakowie oraz w województwie krakowskim w Królestwie Polskim. Zob. spis ADCh, M 3290.

${ }^{37}$ Ze względu na ograniczenia redakcyjne autor nie mógł zamieścić w niniejszym artykule przygotowanego spisu emigrantów, którzy w latach 1831-1833 przewinęli się przez departament Indre, zatytułowanego Zaktady w Châteauroux i departamencie Indre w latach 1831-1833. Sklad osobowy. W tabeli liczącej ponad 40 stron odnotowano informacje dotyczące wieku, zawodu, miejsca pobytu we Francji, żołdu itd. Powyższe dane to rezultat obliczeń własnych, poczynionych na podstawie danych źródłowych, zob. przyp. 31 i 32.

${ }^{38}$ SHAT, XL 47, Réfugiés polonais: affaires générales (1832-1844); Ministère de l'Intérieur au le Ministère de la Guerre, Paris, 11 VII 1832; XL 48, Ministère de l'Intérieur au le Ministère de la Guerre, Paris, 24 VII 1832. Przybyłych na statkach latem 1832 r. skierowano do St. Benoit (28 VIII), Argenton (29 VIII), Châteauroux (30 i 31 VIII) oraz Issoudun (1 VII). 
dla wojskowych. Ustalono miejsca poprzedniego pobytu 607 emigrantów polskich. Z Paryża przybyło 20 osób, z Bourges - 191, z Bordeaux - 158, ze Strasburga - 57, z Besançon - 90, z Le Puy - 55, z Montpellier - 8, z Metzu - 8, z Avignonu - 7, z Limoges $-3, z$ Calais -2 . Po jednej osobie przyjechało z następujących miejscowości: Arras, Belfort, Colmar, Clomes, Lille, Salins, Méziéres, Vesoul ${ }^{39}$.

\section{5. ŻYCIE POLITYCZNE I SPOŁECZNE ZAKŁADÓW}

Polscy wychodźcy w departamencie Indre to przeważnie młodzi mężczyźni pochodzenia szlacheckiego. Niewielu z nich miało skończone studia lub zdobyty zawód. W większości byli kawalerami, młodzi małżonkowie stanowili niewielki procent (3-4 osoby). Wybierając tułactwo, rezygnowali z łaski carskiej amnestii. Znaczyło to także, iż decydowali się na utratę posiadanego majątku i rezygnację z intratnych stanowisk. Dla większości emigrantów cały majątek stanowił podróżny bagaż. Wyjazd, zwłaszcza dla tych pochodzących z Ziem Zabranych, wiązał się z chęcią uniknięcia zesłania na Sybir, wieloletniej służby w armii carskiej czy wręcz z koniecznością ratowania własnej głowy ${ }^{40}$. Niektórzy Polacy zaraz po przyjeździe do departamentu Indre wystąpili o zmianę miejsca pobytu, na przykład Józef Kowaiłło chciał wyjechać do Troyes. Inni, jak Jan Aleksander Delongeaux, Florian Hebnicki, Seweryn Niewiarowski, starali się o pobyt w Paryżu, a powrót do kraju rozważali między innymi Franciszek Hartel i Leonard Droszewski ${ }^{41}$.

W sprawozdaniu prefekta dla ministra spraw wewnętrznych pisano, że we wrześniu 1832 roku doszło w Issoudun do zaburzeń i prowokacji wśród Polaków, którzy przybyli z Bourges, ale dzięki interwencji miejscowych władz spokój został przywrócony. Kilku prowokatorów, w tym Jan Arandt, który z Bourges do Issoudun przybył bez zezwolenia, zostało usuniętych. Z tego dokumentu wynika, że organizacją zakładu w Châteauroux i pobliskim Levroux zajmował się Teofil Światopełk- Mirski $^{42}$. W miarę napływu emigrantów do departamentu Indre powstał tam jeden

${ }^{39}$ Wszystkie ustalenia na podstawie spisów emigrantów oraz słowników biograficznych i opracowań, zob. m.in. ADCh, M 3293; ADCh, M 3342, Administration générale, 1832; ADCh, M 3296, Département de l'Indre. Etat nominatif des Réfugiés Polonais en résidence dans la Ville de Levroux; de Issoudun; de St. Benoit. Zob. także: L. Janowski, Stownik bio-bibliograficzny dawnego Uniwersytetu Wileńskiego, Wilno 1939; R. Gerber, Stownik Uniwersytetu Warszawskiego 1808-1831. Stownik biograficzny, Wrocław 1977; R. Bielecki, Stownik biograficzny oficerów powstania listopadowego, t. I-III, Warszawa 1995-1998, passim; Stownik krzemieńczan 1805-1832, wstęp i oprac. W. Piotrow ski, Piotrków Trybunalski 2005; A. Szmyt, Udzial uczniów i absolwentów Liceum Krzemienieckiego w powstaniu listopadowym [w:] Wokót powstania listopadowego. Zbiór studiów, red. H. Chudzio, J. Pezda, Kraków 2014, s. 207-225.

${ }^{40}$ J. Pezda, op. cit., s. 159.

${ }^{41}$ ADCh, M 3299, Ville de Châteauroux. Réfugiés Polonais. Etat des réfugiés polonais qui..., $18 \times 1832$.

${ }^{42}$ SHAT, XL 47, Copie de la lettre M préfet de département de l'Indre à M le Ministre de l'Intérieur, ce date du 27 Septembre 1832; Ministère de l'Intérieur au le Ministère de la Guerre, Paris, 6 X 1832; 
z aktywniejszych ośrodków politycznych tułactwa. Znaleźli się w nim były redaktor „Gazety Polskiej” Wincenty Cyprysiński i inni znani później działacze demokratyczni, na przykład Robert Chmielewski, Włodzimierz Dmochowski, Tomasz Malinowski ${ }^{43}$. Tajemniczością i dwuznacznością odznaczał się wspomniany wyżej Teofil Światopełk-Mirski. Alina Witkowska zastanawiała się, kim był w rzeczywistości, czy tylko oszustem, dziwakiem, który przywłaszczył sobie tytuł książęcy, czy też agentem Rosji. Przebywając we wsi Thoreau, należącej do gminy Levroux, snuł najdziwniejsze plany dotyczące wychodźstwa, na przykład, że wszyscy powinni opuścić Francję i przenieść się do Australii, albo przynajmniej schronić się w Algierii. Wiele o Mirskim pisał w dzienniku przebywający w dépôt Piotr Kopczyński, według którego podsycał on tylko wśród młodych emigrantów niepokój. Rozsiewał wieści, że rząd francuski przestanie płacić żołd i usunie ich ze swego terytorium. Rozgłaszał, że car Rosji nie dotrzyma postanowień amnestii i wszystkich wyśle na Syberię. Występował również przeciwko niekwestowanemu autorytetowi emigracji, jakim był generał Karol Kniaziewicz ${ }^{44}$.

Za dziennikiem Kopczyńskiego trzeba przyjąć informację, że latem 1832 roku Teofil Światopełk-Mirski w Levroux dobrał sobie do współpracy pułkownika Michała Szulca i księdza Dominika Petrellewicza, wikarego katedry wileńskiej i dowódcę akademików w powstaniu litewskim. „Ci dwaj emigranci stanowili dwuosobowy dwór »księcia Mirskiego « [...] Dziwny ten książę Mirski [...], stół zwalił na Prałata, gospodarstwo na pułkownika, a sam prowadziłby figurę, tylko bieżnia za mała" ${ }^{45}$. Ten ekscentryk ściągnął młodzież z innych zakładów do Thoreau, obiecując znalezienie zatrudnienia, założenie szkoły i biblioteki. Władze francuskie kokietował swym rzekomym tytułem książęcym, opowiadaniem o pochodzeniu z rodu Ruryków i posiadaniu wielkich bogactw w kraju. Zdobył zaufanie Francuzów i pełnił funkcję pośrednika między miejscową administracją a młodzieżą zakładową. Urządził menaż, czyli tani lokal gastronomiczny, który wkrótce zbankrutował. Działalność Mirskiego była powodem wielu kłótni i nieporozumień w zakładzie. W końcu zorientowano się w jego fałszerstwach, intrygach, bezprawnym rozdawnictwie odznaczeń i stopni wojskowych. Poznano, że szerzy zmyślone wieści, że ukrywa korespondencję z innych zakładów i działa na szkodę Polaków. Zdaniem Kopczyńskiego „ks. Petrellewicz pierwszy coś spostrzegł się, że komedia Mirskiego jest właściwie dowcipnym oszustwem, pomaga Mirskiemu oszukać biedną młodzież”46. W kwietniu 1834 roku,

ADCh, M 3294, Rachunki miasta Châteauroux dla Komisji Polskiej, m.in. od miejscowych księgarni, Châteauroux, 24 VII 1832; ADCh, M 3299, List T. Mirskiego i F. Rupejko do prefekta departamentu Indre, Châteauroux, 24 IX 1832.

43 J.N. Janowski, Notatki autobiograficzne 1803-1853, przygotowanie do druku, wstęp i przypisy M. Tyrowicz, Wrocław 1950, s. 338-339, 472-473, 486; S. Kalembka, Wielka Emigracja..., s. 47.

${ }^{44}$ A. Witkowska, Cześć i skandale. O emigracyjnym doświadczeniu Polaków, Gdańsk 1997, s. $163-164$.

45 Biblioteka Polska w Paryżu (dalej: BPP), rkps 413, t. IV, k. 107, Dziennik Piotra Kopczyńskiego, 5-7 X 1832; k. 40, 49 (Châteauroux, 13-15 VII 1832), k. 95-97 (26-28 IX 1832).

${ }^{46}$ Ibidem, k. 107, 5-7 X 1832; ADCh, M 3299, List do T. Mirskiego, 28 VII 1832; List J. Lelewela do ministra spraw wewnętrznych (Paryż, 1 XI 1832) w sprawie Mirskiego i emigrantów polskich w departamencie Indre, List T. Mirskiego do prefekta, Thoreau, 12 XI 1832; Prefekt departamentu Indre 
przebywając dalej w okolicach Levroux, Mirski wystąpił po raz trzeci o amnestię carską i wystosował wiernopoddańczy list do Mikołaja I. W tym czasie w Paryżu wręczył również akt osobistej sumisji na ręce rosyjskiego ambasadora Pozzo di Borgo. Ponieważ wszystkie te zabiegi nie dały rezultatu, a równocześnie był ścigany za długi, w 1834 roku udał się do Algierii, gdzie otrzymał posiadłość ziemską Rassauta koło Algieru, liczącą 4300 hektarów, w której zatrudniał Polaków. Wkrótce zbankrutował, stracił ziemię i powrócił do Francji, po raz kolejny występując z prośbą o łaskę cara. Tym razem (1842) uzyskał amnestię, przeszedł na prawosławie i powrócił do kraju. Przez ogół emigracji uznany został za zdrajcę i renegata ${ }^{47}$. Innym „oryginałem” zakładowym był niejaki Franciszek Jaxa-Dembicki, który w czerwcu 1832 roku został odesłany z zakładu w Lunel do Châteauroux. W drodze zachorowała mu żona i zatrzymał się w Limoges. W listopadzie 1832 roku przybył do Châteauroux, skąd w lutym 1833 roku z rodziną trafił do Paryża. W zakładzie miał fatalną opinię. Występując jako hrabia de Jaxa, wyłudzał pieniądze, stąd sami Polacy ostrzegali przed nim Francuzów, uznając go za oszusta. Podawał się czasem za majora, ale według powszechnej opinii był tylko strażnikiem leśnym. Sądzono go za bezprawne noszenie Legii Honorowej i za różne szalbierstwa, a w maju 1848 roku został ostatecznie wydalony z Francji. Powszechnie za oszusta uważany był także Jan Chrzciciel Eysymont mieszkający w Châtillon. W późniejszym okresie ożenił się z Francuzką, z którą miał dzieci, ale porzucił rodzinę i w 1843 roku wrócił do kraju ${ }^{48}$.

Duże kontrowersje wśród Polaków wzbudzała służba w Legii Cudzoziemskiej, zaangażowanej w podbój Algierii. Już 16 stycznia 1832 roku w Paryżu podjęto decyzję o powołaniu w jej ramach polskiego batalionu. Większość emigrantów protestowała przeciw służbie legionowej, ale część bez oporów do niej przystąpiła ${ }^{49}$. Jak wynika z materiałów archiwalnych, około 20 Polaków zgrupowanych w departamencie Indre zadeklarowało chęć wyjazdu do Algierii. Adnotacje urzędników francuskich wskazują, że zamiary takie zgłaszali między innymi: Benedykt Rel, Michał Mrozinkiewicz, Józef Tilsson, Antoni Topolski, Franciszek Wronecki, Kajetan Gimbułt, Piotr Stankiewicz ${ }^{50}$. Z korespondencji ministerialnej wiadomo, że Józef Jaskierski i Antoni Gralewski, cieszący się dobrą opinią u miejscowego prefekta, również zamierzali się udać do Afryki ${ }^{51}$. W końcu dzięki staraniom władz francuskich niektórzy zostali wysłani do Algierii przez port w Tulonie ${ }^{52}$.

do T. Mirskiego w sprawie polskich emigrantów, 9 IX 1832; L. Gadon, Emigracja polska ..., t. III, s. 203-204; J. Kuzicki, Nieść wiarę..., s. 479-480.

47 J.N. Janowski, op. cit., s. 508; R. Bielecki, Stownik biograficzny..., t. III, s. 155-156.

${ }^{48}$ R. Bielecki, Stownik biograficzny..., t. I, s. 357-358; t. II, s. 25.

${ }^{49}$ Idem, Polacy w Legii Cudzoziemskiej 1831-1879, Warszawa- Łódź 1992, s. 4-7; A. Kasznik, Między Francją a Algieriq. Z dziejów emigracji polskiej, 1832-1856, Wrocław-Kraków 1977, passim.

${ }^{50}$ ADCh, M 3293, Administration générale, 1832, Département de l'Indre. Contrôle des Polonais. Réfugiés envoyés en résidence dans ce departement.

${ }^{51}$ ADCh, M 3299, Ministère de l'Intérieur au Préfet de l'Indre, Paris 10 XII 1832; Le Préfet de l'Indre au Ministère de l'Intérieur, 26 VII 1832; 30 I 1833; SHAT, XL 47, Ministère de l'Intérieur au le Ministère de la Guerre, Paris, 5 IX 1832.

${ }^{52} \mathrm{Na}$ liście pasażerów okrętu do Afryki z departamentu Indre znaleźli się: Wolfgang Krajewski (lat 34, piechota), Marceli Rudzki (lat 29, piechota), Leon Jaszewski, Józef Jaskierski (lat 28, piechota), An- 
Zakłady w departamencie Indre w przeciwieństwie do dépôts wojskowych miały problemy z wykształceniem organizacji wewnętrznej. W pozostałych zakładach utrzymał się podział na kolumny, które w trakcie przemarszu zdołały wykształcić swoją odrębność. W odmiennej sytuacji był zakład w Châteauroux. Uległ on rozczłonkowaniu na kilka ośrodków rozrzuconych po całym departamencie. Każdy z tych ośrodków stanowił zarazem odrębną jednostkę organizacyjną. Pierwszą nieudaną próbę utworzenia samorządu zakładu podjął Julian Kępiński w sierpniu 1832 roku w Levroux. Wybrano radę, której przewodniczył najpierw Władysław Wojnicz, potem Antoni Wolski. Na skutek niesnasek wewnętrznych, kłótni przeciwników i zwolenników Mirskiego, we wrześniu instytucja ta upadła. P. Kopczyński, który wówczas odwiedził „księcia” we wsi, zanotował: „Jeździłem do Thoreau, gdzie Mirski niby to nas dobrze przyjmował, ale poskąpiał, zdziwaczał, ks. Petrollewicz i Szulc chcą go rzucié" 53 . Po paru tygodniach, w październiku 1832 roku, powołano nową radę w Levroux. Jej prezesem został ksiądz Dominik Petrellewicz, członkami zaś: pułkownik Michał Szulc, Wincenty Cyprysiński, Antoni Walewski, Ksawery Rozwadowski, Hieronim Żongołłowicz, Ignacy Żebrowski. Byt nowej rady Polaków w Levroux, powołanej w październiku, również nie okazał się trwały, ponieważ wkrótce zaprzestała swojej działalności. Swary i kłótnie nie ustały, a przywódcy młodzieży studenckiej - ksiądz Dominik Petrellewicz, marszałek Ignacy Zarzecki, Wincenty Cyprysiński i Franciszek Rupejko - wzajemnie się zwalczali ${ }^{54}$.

Ze sprawozdania Komitetu Narodowego Polskiego wiadomo, że „Rodacy w departamencie de l'Indre urządzający się i zawiązujący rady w Châteauroux, Levroux, Châtillon, w październiku i w listopadzie zgłaszali się do komitetu i uwiadamiali go o urządzeniu się swoim" "55. 17 października 1832 roku zawiązała się rada w stolicy departamentu, której prezesem został Antoni Bukaty. Jej byt, podobnie jak tej w sąsiednim Levroux, nie był trwały, ponieważ już 15 stycznia 1833 roku zawiązała się nowa rada Polaków w Châteauroux. W jej skład weszli: Kazimierz Markiewicz, Tomasz Malinowski, Franciszek Krahnas, Michał Sobolewski, Franciszek Patysiewicz, Jan Mieszkowski, Piotr Semenenko. Nie wybrano stałego prezesa, ponieważ demokratycznie postanawiano, że członkowie będą prezydować rotacyjnie. Wybrano

toni Gralewski (lat 22, lansjerzy), Piotr Stankiewicz (lansjerzy), Antoni Klempiński, zob. ADCh, M 3299, Ministère de l'Intérieur au le Ministère de la Guerre, Paris, 19 IX 1832. Na późniejszej liście znaleźli się: Lucjan Kotyński (lat 24, piechota), Józef Tisson (lat 22, piechota), Franciszek Wronecki (lat 23, piechota), Michał Dobrowolski (lat 29, urzędnik służby zdrowia), Franciszek Matrowski, Albert Foscoi de Dubnitz (Foscci), Jakub Pisarzewski (lat 29, piechota), zob. ADCh, M 3299, Ministère de l'Intérieur au le Ministère de la Guerre, Paris, 10 X 1832; Note pour le Bureau de l'Infanterie, 11 XI 1832. W listopadzie 1832 r. paszporty do Tulonu otrzymali: Antoni Klempicki, Konstanty Nidecki, Stanisław Goczałkowski, Michał Mrozinkiewicz, Benedykt Rel i Józef Rymkiewicz, ADCh, M 3299, Ministére de l'Intérieur au Monsieur le Président du Conseil de Ministre, Paris, 14 XI 1832; Rymkiewicz, militaires qui demandent à passer dans le Légion étrangére (dirigés sur Toulon), Marseille, 12 VIII 1832; Ministère de l'Intérieur au Préfet de l'Indre, Paris, 19 IX 1832; Le Préfet de l'Indre au Ministère de l'Intérieur, 30 I 1833.

${ }_{53}$ BPP, rkps 413, t. IV, Dziennik Piotra Kopczyńskiego, k. 68, 17 i 18 VIII 1832.

${ }_{54}^{54}$ L. Gadon, Emigracja polska..., t. III, s. 205-209.

${ }_{55}$ Zdanie sprawy z czynności Komitetu Narodowego Polskiego od końca września 1832 przed ziomkami w tułactwie będacymi, [Paryż 1832], s. 255. 
natomiast stałego sekretarza, którym został Robert Chmielewski, a po jego wyjeździe Piotr Semenenko, późniejszy zmartwychwstaniec ${ }^{56}$. Jak czytamy w deklaracji z 30 stycznia, zakład w Châteauroux ,po długim letargu swoim przebudził się do życia publicznego". Przyczyniły się do tego napływ emigrantów do zakładu (szczególnie studentów) oraz silna potrzeba wewnętrznej organizacji. Pod względem ideowym rada w Châteauroux przyjmowała zasadę „,wszechwładztwa ludu”. Zajęto się sprawami emigracji, do miejscowego prefekta i Ministra Spraw Wewnętrznych wysłano petycje. Korespondentem zakładu w Paryżu został Jan Nepomucen Janowski, a potem Ignacy Płużański. 30 stycznia powołano w Châteauroux sąd honorowy, który miał przeciwdziałać rozluźnieniu wewnętrznej dyscypliny, ale okazał się on instytucją efemeryczną i mało skuteczną. Po uzgodnieniu wspólnych stanowisk z radą Polaków w Le Puy i innymi zakładami przygotowano w Châteauroux petycję do Izby Deputowanych o zniesienie wspomnianego już prawa z 21 kwietnia 1832 roku $^{57}$. Na przełomie 1832 i 1833 roku Polacy mieszkający w dépôts skarżyli się na restrykcje rządu francuskiego. W kwestiach dyscypliny od połowy listopada 1832 roku zaczęto stosować wobec emigrantów przepisy francuskiego wojskowego kodeksu karnego z 13 maja 1818 roku. Duża zmiana w prawnym położeniu emigracji zaszła 1 kwietnia 1833 roku. Od tego dnia bowiem także zakłady „wojskowe” podlegały ministrowi spraw wewnętrznych Apolinaremu hr. d'Argouta. W praktyce oznaczało to: zaostrzenie kontroli nad emigracją, obowiązek cotygodniowego meldowania się u władz lokalnych oraz modyfikację wysokości żołdu ${ }^{58}$.

Rada Polaków w Châteauroux podjęła działalność polityczną, do posłów sejmowych na emigracji zwrócono się z wyrazami zachęty do pracy na rzecz reaktywowania sejmu polskiego. Rady zakładów Châteauroux, Beançon i Le Puy wystosowały pisma domagające się rozpoczęcia obrad bezpośrednio do wojewody Antoniego Ostrowskiego, który wiosną 1832 roku podjął starania na rzecz zwołania sejmu na wychodźstwie. Tym samym organy te pomijały Komitet Narodowy Emigracji Polskiej na czele z generałem Józefem Dwernickim. Nie było to posunięcie przypadkowe. Wyraźnie zlekceważono przedstawicielstwo nie tak dawno wybrane przez zakłady. Podjęto również starania o utworzenie Towarzystwa Wzajemnego Oświecania się i o uruchomienie drukarni polskiej ${ }^{59}$.

Jedną z pierwszych inicjatyw społecznych na emigracji było powołanie 29 listopada 1832 roku Towarzystwa Naukowej Pomocy (TNP) przez księcia Adama Jerzego Czartoryskiego oraz ludzi z jego otoczenia. Organizacja ta zajmowała się pomocą dla uczących się emigrantów. W styczniu 1833 roku siedmiu oficerów z Levroux

${ }^{56}$ L. Gadon, Emigracja polska..., t. III, s. 205-209; L. Kuk, op. cit., s. 56, 58.

${ }^{57}$ BCz, rkps 5332 IV, k. 124, Akta Polaków w zakładach Avignon, Besançon i Bourges. Lata 18321833; [Pismo Wzajemnego Oświecania się] Stepak Wojciech, 1833, nr 6, s. 2; L. Gadon, Emigracja polska..., t. III, s. 206.

${ }^{58}$ SHAT, XL 47, Réfugiés polonais: affaires générales (1832-1844); L. Kuk, op. cit., s. 55-56.

${ }^{59}$ [Pismo Wzajemnego Oświecania się] Stepak Wojciech, 1833, nr 6, s. 2; U. Wencel-Kalembkow a, Działalność gen. Józefa Dwernickiego na emigracji w latach 1832-1848, Warszawa-Poznań-Toruń 1978, s. 37-38. Na temat sejmu na tułactwie zob. m.in.: M. Karpińska, Sejm polski na emigracji 1832-1848. Problemy i pytania badawcze [w:] Wokót powstania..., s. 291-308. 
zwróciło się do księcia z prośbą o wyjednanie u władz francuskich pozwolenia na kontynuację studiów w miastach, gdzie znajdowały się wyższe uczelnie. We Francji zamierzali oni ukończyć medycynę, matematykę i inżynierię̨ ${ }^{60}$. W zakładzie Châteauroux funkcję korespondenta TNP pełnił ksiądz D. Petrellewicz. Duchowny ten na początku 1833 roku na polecenie TNP sporządził listę młodzieży zakładowej, która zamierzała dalej się kształcić. Młodzież litewska pod przewodnictwem księdza Petrellewicza utworzyła organizację samokształceniową pod nazwą Towarzystwo Wzajemnego Oświecania ${ }^{61}$. Na jej czele stanął Franciszek Krahnas, a sekretarzem od 16 lutego 1833 roku był Piotr Semenenko, który wygłaszał na posiedzeniach towarzystwa referaty na temat historii powszechnej i religii ${ }^{62}$. Podobna organizacja powstała wcześniej w Besançon. Zakład w Châteauroux planował systematyczne samokształcenie w różnych dziedzinach. Od TNP domagano się przysłania książek z geografii, geologii, fizyki i gramatyki języka francuskiego, polskiego i niemieckiego. Rada TNP przeznaczyła na książki 120 franków, które odesłano do zakładu. Ksiądz Petrellewicz zamierzał założyć w Châteauroux szkołę dla dzieci emigrantów i szeregowych żołnierzy. Problemem były nadal długi wychodźców, wynikające czasem z lekkomyślnego stylu życia. W związku z tym dochodziło do przykrych sytuacji między dłużnikami a wierzycielami, zwłaszcza przy wypłacie żołdu. F. Krahnas wydał nawet odezwę, aby kwestie te były rozstrzygane polubownie. Innym dokumentem była deklaracja zakładu, że TNP uznawali za organizację prywatną, mimo wdzięczności dla jej poczynań. Zapewne ze względu na osoby o konserwatywnym światopoglądzie zasiadające we władzach TNP zakład w Châteauroux zabraniał im ingerowania w życie emigracyjne. W związku z rozwiązaniem zakładów departamentu Indre po kilku miesiącach współpracy z TNP organizacja samokształceniowa upadła. Dzięki zabiegom Towarzystwa Wzajemnego Oświecania, jeszcze wiosną i latem 1833 roku, pewna grupa emigrantów - byłych studentów Uniwersytetu Wileńskiego - podjęła jednak naukę na francuskich uczelniach ${ }^{63}$. Zapoczątkowanie prac naukowo-oświatowych, zakładanie placówek o zadaniach popularnonaukowych i półuniwersyteckich na prowincji francuskiej przerwane zostało również z powodu wydarzeń politycznych związanych z upadkiem Komitetu Narodowego Polski (KNP), organizacją wypraw węglarskich i krystalizowania się Towarzystwa Demokratycznego Polski (TDP). Do Poitiers oraz Paryża wyjechali prezes i sekretarz

${ }^{60}$ BPP, rkps 612, Akta kasy 1832-1834, k. 24, 28, 117-141. Archiwum Towarzystwa Pomocy Naukowej. Protokół posiedzenia TNP z dnia 24 II i 27 III 1833.

${ }^{61}$ BPP, rkps 612, k. 27, 32, Protokoły posiedzenia TNP z dnia 11 III, 29 IV, 17 XI 1833; L. Gadon, Emigracja polska ..., t. III, s. 206-208.

${ }^{62}$ ADCh, M 3297, P. Semenenko au le préfet departament de l'Indre; B. Micewski, Semenenko Piotr [w:] Polski Stownik Biograficzny, t. 36, Warszawa-Wrocław-Kraków 1995-1996, s. 220.

${ }_{63}$ BPP, rkps 612, k. 27, 32, Protokoły posiedzenia TNP z dnia 11 III, 29 IV, 17 XI 1833; ADCh, M 3289, Petycja 24 emigrantów polskich przysłana Ministerstwu Spraw Wewnętrznych, 28 XI 1832; ADCh, M 3289, Etat nominatif des Réfugiés Polonais...; J. Kuzicki, Nieść wiarę..., s. 538-540. Więcej o studiach Polaków we Francji zob. B. Konarska, Polskie drogi emigracyjne. Emigranci polscy na studiach we Francji 1832-1848, Warszawa 1986, passim. 
Towarzystwa Wzajemnego Oświecenia. F. Krahnas został sekretarzem Sekcji Poitiers TDP, a P. Semenenko zasiadł we władzach Sekcji Centralnej ${ }^{64}$.

Członkowie dépôts departamentu Indre byli związani $\mathrm{z}$ ukonstytuowanym 15 grudnia 1831 roku Komitetem Narodowym Polskim z Joachimem Lelewelem na czele. Wyróżniał się tutaj Wincenty Cyprysiński, który od lutego 1832 roku stał się przedstawicielem KNP najpierw w Strasburgu, a następnie w Châteauroux i Levroux $^{65}$. Organizacja ta podejmowała walkę z obozem księcia Adama Jerzego Czartoryskiego, występując przeciwko utworzeniu Legii Cudzoziemskiej w Algierii i Portugalii. KNP przypisywał sobie zadanie reprezentowania narodu i wychodźstwa przed rządami i narodami europejskimi, w praktyce jednak skupiał się na redagowaniu i rozsyłaniu rezolucji. Za pośrednictwem Komitetu Narodowego Polskiego, Komitet Franko-Polski w Metz przekazał „dla tułaczów zakładu Châteauroux” 500 franków ${ }^{66}$. Wiosną 1832 roku rada Polaków w Awinionie wystąpiła z projektem powołania Rady Centralnej we Francji Zebranych. Pomysł ten nie zyskał przychylności w Besançon. W kwietniu 1832 roku dążono do zreformowania KNP i utworzenia Rady Centralnej przez dokooptowanie księcia Czartoryskiego oraz ludzi z nim związanych. Zapewniano, że zakład nie ma zamiaru obalania Komitetu, ale dąży do tego, aby reprezentował on cały naród i emigrantów. Wobec różnicy poglądów zrodził się w tym czasie nowy pomysł utworzenia delegacji złożonej z generałów. Miała ona egzystować obok KNP i reprezentować interesy emigrantów wobec rządu francuskiego. Dépôts w Bourges i Châteauroux, wezwane przez zakład w Besançon do włączenia się do wspólnych narad, nie udzieliły odpowiedzi. Zakład w Bourges był bowiem w kwietniu i maju 1832 roku targany wewnętrznymi sporami dotyczącymi jego organizacji, a w dépôt Châteauroux rada Polaków, o czym wspominałem, zorganizowała się dopiero w sierpniu. Ostatecznie większość osób powołanych do Delegacji nie kwapiła się do podejmowania działalności, obawiając się komplikacji. Tak więc delegacja szybko zakończyła swój byt ${ }^{67} .29$ maja 1832 roku KNP wystosował Adres tułaczów polskich we Francji do izby niższej Wielkiej Brytanii i Irlandii. Odezwę podpisało 18 emigrantów z zakładu Châteauroux, między innymi Teofil Światopełk-Mirski, pułkownik Michał Szulc, ksiądz Dominik Petrellewicz, Michał Zdzitowiecki, Józef Rymkiewicz, Michał Szaniawski, Antoni Wolski, Hipolit Klimaszewski, Antoni Bukaty ${ }^{68}$. Po rozpędzeniu KNP przez policję w Paryżu, 24 grudnia 1832 roku, gdy interweniowała ambasada carska po wydaniu odezwy do Rosjan, członkowie organizacji Lelewela otrzymali pismo z zakładu w Châteauroux, w którym wyrażono wdzięczność za poświęcenie i trudy poniesione dla sprawy ojczystej. Czytamy tam:

${ }^{64}$ J.N. Janowski, op. cit., s. 505; D. Rederowa, op. cit., s. 88-89.

${ }^{65}$ R. Bielecki, Stownik biograficzny..., t. I, s. 316.

${ }^{66}$ SHAT, XL 47, 15e Division Militaire au le Ministère de la Guerre, Bourges, 12 X 1832; Zdanie sprawy z czynności Komitetu Narodowego Polskiego od końca września 1832 przed ziomkami w tułactwie będacymi, s. 290; S. Kalembka, Wielka Emigracja..., s. 91.

${ }^{67}$ S. Sokołowska, Młoda Polska. Z dziejów ugrupowań demokratycznych Wielkiej Emigracji, Wrocław-Warszawa-Kraków-Gdańsk 1972, s. 20-22; S. Kalembka, Wielka Emigracja..., s. 95-96.

${ }^{68}$ Zdanie sprawy z czynności Komitetu Narodowego Polskiego od 15 kwietnia do końca września 1832 przed Ogótem Paryskim złożone, s. 220. 
„Ozwał się dworzec carski i usłuchał Palais Royale i Tuillerie [...]. Ziomkowie! Zakład wychodźców cywilny przez samą sympatię zbliżał się zawsze ku wam. Zasługi wasze przedrewolucyjne po większej części w życiu cywilnym znane były"69.

Do departamentu Indre dotarły wieści o przygotowywanych planach wyprawy na ziemie polskie wczesną wiosną 1833 roku. Z korespondencji Cyprysińskiego wynika, że jako węglarz zajmował się werbunkiem uczestników partyzantki Józefa Zaliwskiego nie tylko w Levroux czy Châteauroux, ale i w zakładzie w Besançon ${ }^{70}$. Z zakładu w Châteauroux w kierunku Galicji udał się ksiądz Eugeniusz Kopecki, były kapelan 26 Pułku Piechoty Liniowej. W marcu 1833 roku został jednak zatrzymany przez policję austriacką i przez port $\mathrm{w}$ Trieście wysłany przymusowo do Ameryki Północnej ${ }^{71}$. Zakład w Levroux zaprotestował 28 marca 1833 roku przeciwko amnestii carskiej. W zakładzie tym mer ogłosił pismo rządowe, w którym usiłowano skłonić Polaków do przyjęcia łaski Mikołaja I. W publicznym piśmie podkreślano: „Gdyby nawet, co jest niepodobna, amnestia ogłoszona przez cesarza Mikołaja mogła się do nas stosować i miała uzasadnioną gwarancję, żaden z nas nie poświęci pryncypiów swoich osobistym korzyściom, jakieby znaleźć mógł w Ojczyźnie"72.

Młodzi oficerowie i podoficerowie w departamencie Indre chcieli wziąć udział wiosną 1833 roku w rewolucji we Frankfurcie nad Menem. Wiedzieli o przygotowaniach do takich działań podejmowanych w innych zakładach. Gotowość do wymarszu zgłaszali tułacze polscy z Châtillon. Na przeszkodzie w realizacji tych planów stanęły władze francuskie, które wysłały oddziały wojskowe „dla zniweczenia zamiaru, równie jak dla wzbronienia powrotu tym, którzy już przeszli byli granice. Wielu rodakom, szczególniej z zakładu Châterauroux, którzy żądali paszportów za granicę [rząd - przyp. J.K.] udzielić ich w żaden sposób nie chciał"73. Po nieszczęsnej wyprawie frankfurckiej zakład w Châteauroux przekazał 500 franków ze składki na rzecz emigrantów polskich w Szwajcarii. W tym celu urządzono koncert muzyczny, podczas którego występowali Aleksander Tarnowski, Michał Wodpol, Józef Miranowicz ${ }^{74}$. Jak wynika ze sprawozdania władz francuskich, w Levroux i Châtillon ujawnili się agitatorzy polityczni. Do wybijających się postaci należeli: Kazimierz Lewandowki, Józef Sokołowski, Stanisław Polkowski i profesor Antoni Walewski ${ }^{75}$.

17 marca 1832 roku, w rezultacie rozłamu w Komitecie Narodowym Polskim, rozpoczęło swój trzydziestoletni byt Towarzystwo Demokratyczne Polskie. Emigranci

${ }^{69}$ Adres Polaków w departamencie de l'Indre będących do czlonków b. Komitetu Narodowego Polskiego [w:] Zdanie sprawy z czynności Komitetu Narodowego Polskiego od końca września 1832 przed ziomkami w tułactwie będacymi, s. 286-287.

${ }^{70}$ S. Sokołowska przytacza w tym kontekście list W. Cyprysińskiego do J.N. Janowskiego z 1833 r. Zob. S. Sokołowska, op. cit., s. 35.

${ }^{71}$ J. Kuzicki, Nieść wiarę..., s. 485, 748.

72 „Pielgrzym Polski. Pismo Polityczne i Literackie”, IV-VI 1833, półarkusz 2, cz. 1, s. 8.

73 „Pielgrzym Polski. Pismo Polityczne i Literackie”, IV-VI 1833, półarkusz 3, cz. 1, s. 10.

${ }^{74}$ Rachunek kasy od czasu jej utworzenia to jest od d. 8go kwietnia do 1go grudnia 1833 roku [w:] Zdanie sprawy z czynności emigracji polskiej w Szwajcarii, [Paryż 1833] s. 4; Zdanie sprawy z czynności Komitetu Narodowego Polskiego od końca września 1832 przed ziomkami w tułactwie będacymi, s. 260; L. Gadon, Emigracja polska ..., t. III, s. 209.

75 ADCh, M 3299, Le maire de Levroux à Monsieur la Préfet de l’Indre, Levroux, 22 VIII, 19 X 1832. 
z departamentu Indre późno, bo dopiero latem 1833 roku, przystą̧ili do organizacji. Komórka terenowa TDP powstała w Châteauroux w lipcu i liczyła kilkudziesięciu członków. Na posiedzeniach odbytych 6, 18 i 22 sierpnia tego roku paryski Komitet Centralny przyjął do TDP stu kilkudziesięciu członków, głównie z Châteauroux i Bourges. W ten sposób liczba członków wzrosła ze 167 do 326.18 sierpnia przyjęto w Paryżu przybyłych z departamentu Indre Piotra Semenenkę i Wiktora Zienkowicza, a z Châteauroux - Józefa Wysockiego, Tomasza Krzyżanowskiego, a także Wincentego Cyprysińskiego, który poprzednio był związany z Lelewelem. Wkrótce owi emigranci stali się prężnymi działaczami TDP ${ }^{76}$. W archiwum departamentu Indre w Châteauroux zachowała się litografowana lista członków TDP z informacją o miejscu ich zamieszkania ${ }^{77}$. Prawdopodobnie część demokratycznych działaczy z Châteauroux wchodziła w skład miejscowej loży wolnomularskiej „Amis des Sciences”, podlegającej Wielkiemu Wschodowi Francji, a inni byli związani ze strukturami węglarskimi ${ }^{78}$. Jednym z ostatnich politycznych wystąpień wychodźców polskich w Châteauroux było ogłoszenie na nadzwyczajnym posiedzeniu 18 lipca 1833 roku, że agitatorzy generała Józefa Bema w Châteauroux - mimo ochrony żandarmerii francuskiej - „okryci sromotą, opuścić zakład musieli”. Chodziło tutaj o Józefa Raczkowskiego i Tomasza Krzyżanowskiego, których przed linczem ze strony rodaków w Châteauroux ocalili wieśniacy zgromadzeni na targu. 31 lipca ogół zakładowy wydał deklarację, w której za list aprobujący zamiary generała J. Bema ogłaszano zdrajcą księcia Czartoryskiego ${ }^{79}$. Wydarzenia te miały związek z podjętymi przez Bema próbami zorganizowania legii polskiej w służbie portugalskiej. Demokratów szczególnie oburzał fakt, że Polacy mieli służyć w oddziałach najemnych ${ }^{80}$. W zakładach departamentu Indre, w przeciwieństwie do innych dépôts, grupa zwolenników księcia Adama Jerzego Czartoryskiego nie odgrywała większej roli. Jak można przypuszczać, ze względu na cywilny charakter zakładów nie było konserwatywnej starszyzny wojskowej, a wśród braci studenckiej i urzędniczej dominowali demokraci.

Polacy starali się przedstawić swoje problemy wewnętrzne prefektowi, ale nie otrzymali audiencji i tylko na piśmie zdołali złożyć swe zażalenia. Skarżyli się, że za poglądy polityczne są relegowani, nie mogą nawet odwiedzać krewnych lub przyjaciół $\mathrm{w}$ innych miastach departamentu bez pozwolenia władz. Według nich upokarzająca była wypłata żołdu, ponieważ musieli ,jak żebracy” czekać na płatnika przed ratuszem. Zawodziła również komunikacja. Ogłaszane przez doboszy rozkazy

${ }^{76}$ S. Kalembka, Towarzystwo Demokratyczne Polskie w latach 1832-1846, Torun 1966, s. 34-35.

77 ADCh, M 3290, Liste nominative des Membres de Société Démocratique Polonaise.

${ }^{78}$ L. Hass, „Diaspora” polskiego wolnomularstwa (1821-1908), „Przegląd Historyczny” 1971, t. $62 / 2$, s. 208.

${ }^{79}$ Archives Nationales Paris - Archiwum Narodowe w Paryżu (AN), BB 18 - 1217 - Dossier 9290/A 7. Agitation à Châteauroux causée par le projet d'enrôlement de réfugiés polonais au service de Dom Pedro. Juillet 1833; ADCh, M 3292 - Réfugiés polonais, enrôlement de Polonais pour l'expédition projetée par le général Bem (instructions, correspondance, subsides), 1833; ADCh, M 3294, Pismo emigrantów polskich do prefekta departamentu Indre wraz z podpisami, Châterauroux, 16 VII 1833; „Pielgrzym Polski. Pismo Polityczne i Literackie" 1833, półarkusz 19-20, cz. 2, s. 79; L. Gadon, Emigracja polska..., t. III, s. 209.

${ }^{80}$ Więcej zob. H. Chudzio, Egipt w idei legionowej Wielkiej Emigracji, Kraków 2014, s. 44-54. 
rządowe tyczące się emigrantów często były niezrozumiałe dla tych, którzy nie znali języka francuskiego. Prefekt z kolei ze swej strony narzekał na „wałęsanie się” Polaków i częstą zmianę przez nich miejsca zamieszkania. Z patologicznymi zjawiskami walczyła rada Polaków, wydając 25 czerwca 1833 roku okólnik przeciwko włóczęgostwu i naciskając na merów, aby nie wydawali żadnemu Polakowi paszportu, póki nie spłaci długów ${ }^{81}$.

Emigranci w departamencie nie stronili od kontaktów z miejscową ludnością. W czerwcu 1832 roku Polacy z zakładu w Levroux zostali zaproszeni do udziału w uroczystościach religijnych. Piotr Kopczyński wraz z pułkownikiem Michałem Szulcem i pewną liczbą polskich oficerów wzięli udział w uroczystej procesji Bożego Ciała. Jej ceremoniał Polacy obserwowali z zainteresowaniem. „Ta procesja dla mnie dziwna - pisał P. Kopczyński - ołtarze jak i u nas w różnych miejscach, ale ulice, którędy do nich idzie ta procesja, zawieszone białymi prześcieradłami, gwardia narodowa pod bronią idzie w dwa rzędy jak u nas studenci, oficerowie obwieszeni krzyżami legii, tuż za księżmi, pułkownik komenderuje z krzykiem i stukiem halabardy jak na placu marsowym" "82. Poza uroczystościami religijnymi P. Kopczyński opisywał polowania w okolicznych lasach, w których brali udział Polacy, urozmaicając w ten sposób niedogodności tułaczej egzystencji ${ }^{83}$.

W dépôts uroczyście obchodzono święta narodowe. Nie posiadamy informacji, czy w Châteauroux uczczono drugą rocznicę wybuchu powstania listopadowego 29 listopada 1832 roku. Możliwe, że ze względu na fazę organizacyjną zakładu uroczystości takie się nie odbyły. W kwietniu 1833 roku rocznica powstania litewskiego ożywiła społeczność emigrantów w Levroux. Tam Towarzystwo Przyjaciół Literatury odbyło posiedzenie nadzwyczajne, w czasie którego przemawiali Wincenty Cyprysiński, Jakub Drohomirecki, Antoni Korsak i Franciszek Mickanowski. W Châteauroux zorganizowano podobne uroczystości, a w ich trakcie głos zabierali Piotr Semenenko i Mikołaj Rahoza ${ }^{84}$. Jak wynika z relacji prasowych, w zakładach departamentu Indre szczególną wagę przywiązywano do obchodów rocznicy uchwalenia Konstytucji 3 maja. Centralne uroczystości odbyły się 3 maja 1833 roku w Châteauroux. Uroczystość zgromadziła ponad 400 Polaków, którzy udali się do pobliskiego gaju z chorągwią narodową, z herbem Orła Białego i Pogoni oraz czapką wolności (prawdopodobnie frygijską), wyobrażającą majestat ludu. W miejscu uroczystości zorganizowano koncert pieśni patriotycznych w wykonaniu amatorskiej orkiestry. Po licznych przemowach odczytano strofy poezji i rozdano 300 egzemplarzy jednego z dzieł Lelewela. Na koniec przeczytano przysłaną z Tours odezwę podpisaną przez Joachima Lelewela i Leonarda Chodźkę z podziękowaniem ,za życzliwe słowa dla nas z Paryża rozpędzonych" ${ }^{\text {"5 }}$. Echa tych obchodów pobrzmiewały jeszcze kilka tygodni, ponieważ w „Pielgrzymie Polskim” pod koniec maja ukazała się korespondencja

${ }^{81}$ L. Gadon, Emigracja polska ..., t. III, s. 206, 209; B. Konarska, op. cit., s. 20-21.

82 BPP, rkps 413, t. IV, k. 41, Dziennik Piotra Kopczyńskiego, 24 VI 1832.

${ }^{83}$ Ibidem, k. 40-41, 23-24 VI 1832.

${ }^{84}$ „Pielgrzym Polski. Pismo Polityczne i Literackie”, IV-VI 1833, półarkusz 1, cz. 1, s. 44.

85 „Pielgrzym Polski. Pismo Polityczne i Literackie”, IV-VI 1833, półarkusz 7, cz. 1, s. 26-27;

L. Gadon, Emigracja polska..., t. III, s. 208-209. 
z Châteauroux podpisana przez sekretarza rady Roberta Chmielewskiego. Odnosząc się do poprzedniej relacji z uroczystości trzeciomajowych, sekretarz stwierdził, że idea zgromadzenia w Châteauroux nie została w pełni wyjaśniona i wymaga sprostowania. Było nią przypomnienie praw należnych ludowi polskiemu, a zgromadzenie składające się z właścicieli ziemskich uczciło pamięć przodków, którzy zgodzili na koncesje na rzecz chłopów i mieszczan. Przyjęto deklarację, „iż pierwszy krok zrobiony na ziemi polskiej będzie krokiem zupełnego oswobodzenia włościan" W czerwcu i lipcu 1833 roku w departamencie Indre uczczono pamięć Polaków, którzy oddali życie za Ojczyznę w wyprawie Józefa Zaliwskiego. W Châteauroux podczas zgromadzenia ogólnego przemawiali Józef Kuczyński, Aleksander Kukowicz i Wincenty Cyprysiński. 5 lipca w Levroux, w czasie obchodów pamięci nowych męczenników narodowych, zorganizowanych przez Towarzystwo Przyjaciół Polski, Józef Franciszek Kołosowski odczytał między innymi patriotyczny wiersz wyrażający oburzenie z powodu poniżenia ludów europejskich i tryumfu tyranii. W lipcu kapelani polscy w Châteauroux zorganizowali nabożeństwo religijno-patriotyczne i odprawili mszę żałobną za zmarłych w wyprawie 1833 roku $^{87}$. Prawdopodobnie loże masońskie w Levroux i Châteauroux włączyły się w obchody uroczystości żałobnych zainicjowanych 3 lipca 1833 roku w paryskiej loży „Trinté Indivisible” na cześć jej członka Kaspra Dziewickiego, poległego w wyprawie Zaliwskiego ${ }^{88}$.

Zakład w Châteauroux zaczął się powoli wyludniać już w kwietniu 1833 roku. W tym miesiącu opuściło stolicę departamentu 17 Polaków. Za pozwoleniem władz do Paryża wyjechali Aleksander Bułhak, Antoni Bukaty, Ignacy Szultz czy Kajetan Witkowski, zaś na Wyspy Brytyjskie udali się między innymi Marceli Rudzki, Franciszek Wronecki, Mikołaj Weber i Stanisław Jordan. Dodatkowo kilku emigrantów jeszcze wczesną wiosną opuściło zakład: Alojzy Orchowski, Kornel Wolszlger, Stanisław Leonowicz, Dionizy Piotrowski, Postempski Ignacy i Stanisław Dembicki. Jeszcze inni tułacze, jak Grzegorz Gaudysz, Franciszek Bogusławski i Franciszek Szyłański, ze względu na leczenie udali się do większych ośrodków ${ }^{89}$. Po rozwiązaniu zakładów latem 1833 roku, zdaniem L. Gadona, w departamencie Indre we wrześniu 1833 roku pozostało 67 Polaków, w tym w stolicy departamentu - 27. Zawiązała się nowa Rada Ogółu, na której czele ponownie stanął Antoni Bukaty, a jej sekretarzem został Seweryn Gostyński. Komitet wykonawczy rady liczył 5 członków ${ }^{90}$. Trzeba przy tym nadmienić, że poza Polakami w Châteauroux przebywali emigranci hiszpańscy, których usunięto w marcu 1834 roku $^{91}$. W grudniu 1834 roku w Châteauroux znajdowało się 46 oficerów i 52 podoficerów, razem 98 Polaków ${ }^{92}$.

86 „Pielgrzym Polski. Pismo Polityczne i Literackie”, IV-VI 1833, półarkusz 12, cz. 1, s. 48.

87 „Pielgrzym Polski. Pismo Polityczne i Literackie” 1833, półarkusz 17-18, cz. 2, s. 69; J. Kuzicki, Nieść wiarę..., s. 230, 233.

${ }^{88}$ L. Hass, op. cit., s. 208.

${ }^{89} \mathrm{ADCh}$, Etat des Polonais présents et absents à Châteauroux le 21 mars; 1, 15, 30 avril 1833.

${ }^{90}$ L. Gadon, Emigracja polska..., t. III, s. 210.

${ }^{91}$ P. Harismendy, op. cit., s. 43.

92 SHAT, XL 48, Situation des réfugiés Polonais en résidence dans les division militaires, au 1er décembre 1834, 3 I 1835. 
Według danych rządowych, które przytoczył emigracyjny „Dziennik Narodowy”, w 1841 roku w departamencie Indre łącznie przebywało 46 tułaczy z nadwiślańskich i nadniemeńskich krain, przy czym 34 pobierało żołd, a 12 nie korzystało ze wsparcia rządowego ${ }^{93}$. Na podstawie spisów archiwalnych można stwierdzić, że 1 października 1848 roku przebywało w regionie centralnym 25 polskich emigrantów. Liczba ta ciągle spadała i trzy lata później w Issoudun zamieszkiwało zaledwie 10 Polaków, a w całym departamencie Indre 24 samotnych mężczyzn, mających na ogół więcej niż 40 lat $^{94}$.

Reasumując, można stwierdzić, że przez zakłady departamentu Indre w latach 1831-1833 przewinęło się ponad 630 tułaczy polskich. Większość z nich stanowili studenci (z Uniwersytetu Wileńskiego), młodzi urzędnicy i przedstawiciele wolnych zawodów. Pochodzili z przedrozbiorowych terenów dawnej Rzeczypospolitej (Litwy, Wołynia i Podola). Podobnie jak w innych zakładach, często popadali w alkoholizm, uprawiali hazard, włóczęgostwo, towarzyszyły im ciągłe kłótnie i swary. Nie brakowało „niebieskich ptaszków”, chociaż były to jednostki. Emigranci ulegali też „politykierstwu”, a spory wewnętrzne zaważyły na słabej skuteczności w działaniu rad zakładowych. Pomimo narzekań na marazm tułaczej egzystencji na francuskiej prowincji udało się Polakom skutecznie włączyć w polityczne i społeczne życie emigracji. Wysyłali petycje i protesty, organizowali obchody świąt narodowych. Emigranci z departamentu Indre należeli głównie do demokratycznych organizacji, poczynając od Komitetu Narodowego Polski, poprzez poręby węglarskie, a kończąc na Towarzystwie Demokratycznym Polskim. Nieliczni zaliczali się do zwolenników obozu księcia Adama Jerzego Czartoryskiego. Cechą wyróżniającą młodzież emigracyjną departamentu Indre były duże ambicje edukacyjne. Od początku pobytu domagali się od rządu umożliwienia im podjęcia studiów na francuskich uczelniach. W wielu przypadkach dzięki własnej determinacji emigranci ukończyli uniwersytety i politechniki, zdobywając wykształcenie. Jako lekarze, prawnicy, inżynierowie, nie tylko zdobyli odpowiedni status społeczny, ale także służyli państwu francuskiemu i Ojczyźnie swoją pracą.

93 „Dziennik Narodowy”, 19 VI 1841, nr 12, s. 48.

94 ADCh, M 3349, Département de l'Indre. Contrôle nominatif et particulier des Réfugiés Polonais subventionnés au 1er Octobre 1848; ADCh, M 3351, Département de 1'Indre. Contrôle nominatif des Réfugiés Polonais subventionnés au 23 Septembre 1851; Département de l'Indre. Contrôle nominatif et particulier des Réfugiés Polonais subventionnés au 1er Octobre 1851. 


\section{BIBLIOGRAFIA}

\section{Źródła archiwalne}

Archiwum departamentu Indre w Châteauroux (Archives départementales de l'Indre, Châteauroux, ADCh)

M 3290, Liste nominative des Membres de Société Démocratique Polonaise.

M 3292, Réfugiés polonais, enrôlement de Polonais pour l'expédition projetée par le général Bem (instructions, correspondance, subsides), 1833.

M 3293, Administration générale, 1832, Département de l'Indre. Contrôle des Polonais. Réfugiés envoyés en résidence dans ce departement; Liste des passagers Polonais arrivés en rivierre de Bordeaux sur le naviere Prussien la Vigilante mouillé en rade de Pauillac le 11 auot 1832. Movité à Bordeaux les passagers débarqués et remis à la disposition du département de la guerre le...

M 3294, Réfugiés Polonais. Pièces et correspondance concernant les 160 réfugiés dirigés de Bordeaux sur Chateauroux et leur repartetion dans le départiens, Aout 1832.

M 3295, Souspréfecture de La Chate au Préfet de l'Indre, La Chatre, 19, 24 IX 1832.

M 3296, Département de l'Indre. Etat nominatif des Réfugiés Polonais en résidence dans la Ville de Levroux; Département de l'Indre. Etat nominatif des Réfugiés Polonais en résidence dans la Ville de Issoudun; Département de l'Indre. Etat nominatif des Réfugiés Polonais en résidence dans la Ville de St. Benoit; Réfugiés polonais, listes nominatives des réfugiés résidant dans divers centres de l'Indre (Argenton, La Balanc, Châteauroux...), 1833.

M 3299, Le maire de Levroux à Monsieur la Préfet de l'Indre, Levroux, 22 VIII, 19 X 1832; Ville de Châteauroux. Réfugiés Polonais. Etat des réfugiés polonais qui..., $18 \times 1832$.

M 3302, Ministère de l'Intérieur au Préfet de l'Indre, Paris, 15 X 1832.

M 3342, Administration générale, Châteauroux. Etat nominatif des Réfugiés Polonais.

M 3349, Département de l'Indre. Contrôle nominatif et particulier des Réfugiés Polonais subventionnés au 1er Octobre 1848.

M 3351, Département de l'Indre. Contrôle nominatif des Réfugiés Polonais subventionnés au 23 Septembre 1851; Département de l'Indre. Contrôle nominatif et particulier des Réfugiés Polonais subventionnés au 1er Octobre 1851.

Archiwum Ministerstwa Obrony Francji w Vincennes (Service Historique de l'Armée de Terre, SHAT)

XL 47-48, Réfugiés polonais: affaires générales (1832-1844).

Archiwum Narodowe w Paryżu (Archives Nationales Paris - AN)

BB 18 - 1217 - Dossier 9290/A 7. Agitation à Châteauroux causée par le projet d'enrôlement de réfugiés polonais au service de Dom Pedro. Juillet 1833.

Biblioteka Czartoryskich w Krakowie (BCz)

rkps 562, Spisy emigrantów polskich. Spisy emigrantów polskich w poszczególnych zakładach.

rkps 5332 IV, Akta Polaków w zakładach Avignon, Besançon i Bourges. Lata 1832-1833.

Biblioteka Polska w Paryżu (BPP)

rkps 413, t. IV, Dziennik Piotra Kopczyńskiego. 
rkps 565, Lista emigrantów z Châteauroux.

rkps 612, Akta kasy 1832-1834, Archiwum Towarzystwa Pomocy Naukowej.

\section{Źródła drukowane}

Janowski J.N., Notatki autobiograficzne 1803-1853, przygotowanie do druku, wstęp i przypisy M. Tyrowicz, Wrocław 1950.

Zdanie sprawy z czynności emigracji polskiej w Szwajcarii, [Paryż 1833].

Zdanie sprawy z czynności Komitetu Narodowego Polskiego od 15 kwietnia do końca września 1832 przed Ogółem Paryskim złożone, [Paryż 1832].

Zdanie sprawy z czynności Komitetu Narodowego Polskiego od końca września 1832 przed ziomkami w tułactwie będacymi, [Paryż 1832].

\section{Prasa}

„Dziennik Narodowy”, 19 VI 1841, nr 12.

„Pielgrzym Polski”. Pismo polityczne i literackie, Paryż 1833.

[Pismo Wzajemnego Oświecania się], Stepak Wojciech, 1833, nr 6.

\section{Opracowania}

Bielecki R., Polacy w Legii Cudzoziemskiej 1831-1879, Warszawa-Lódź 1992.

Bielecki R., Stownik biograficzny oficerów powstania listopadowego, t. I-III, Warszawa 1995-1998.

Bielecki R., Zarys rozproszenia Wielkiej Emigracji we Francji 1831-1837. Materiały z archiwów francuskich, Warszawa-Łódź 1986.

Biographie des hommes du jour industriels, conseillers-d'État..., t. V, p. II, par G. Sarrut, B. Saint-Edme, Paris 1853.

Chudzio H., Egipt w idei legionowej Wielkiej Emigracji, Kraków 2014.

Corbes H., Les émigrés polonais dans les Côtes-du-Nord de 1833 à 1870, „Société d'émulation des Côtes-du-Nord" 1970, s. 80-97.

Dupeux G., Les migrations internationales de la fin du XVIII e siècle à nos jours, Paris 1980.

Fauconneau-Dufresne, Histoire de Déols et de Chateauroux par le Dr..., Chateauroux 1878.

Feduszka J., Powstanie listopadowe na Litwie $i$ Żmudzi, „Teka Komitetu Historycznego Oddziału Lubelskiego PAN" 2004, z. 1, s. 110-160.

Gadon L., Emigracja polska. Pierwsze lata po upadku powstania listopadowego, t. I-III, Kraków-1902.

Gerber R., Stownik Uniwersytetu Warszawskiego 1808-1831. Słownik biograficzny, Wroclaw 1977.

Gouy J.-C., Les réfugiés polonais au Puy après l'insurrection de 1830, „Cahiers d'Histoire” 1979 , no. 3, s. 78-87.

Harismendy P., Les réfugiés politiques en Bretagne (1830-1848), „Annales de Bretagne et des Pays de l'Ouest" 2002, t. 109, no. 4, s. 41-58. 
Hass L., „Diaspora” polskiego wolnomularstwa (1821-1908), „Przegląd Historyczny” 1971, t. $62 / 2$, s. 197-224.

Histoire des villes de France avec une introduction generale pour chaque Artstide Guilbert..., t. IV, Paris 1845.

Janowski L., Stownik bio-bibliograficzny dawnego Uniwersytetu Wileńskiego, Wilno 1939. Kalembka S., Towarzystwo Demokratyczne Polskie w latach 1832-1846, Torun 1966.

Kalembka S., Wielka Emigracja 1831-1863, Toruń 2003.

Karpińska A., Zakład emigracyjny w Besançon, „Studia i Materiały do Historii Wojskowości" 1985, t. 28, s. 184-197.

Karpińska M., Sejm polski na emigracji 1832-1848. Problemy i pytania badawcze [w:] Wokót powstania listopadowego. Zbiór studiów, red. H. Chudzio, J. Pezda, Kraków 2014, s.

Kasznik A., Między Francją a Algieria. Z dziejów emigracji polskiej, 1832-1856, Wrocław-Kraków 1977.

Konarska B., Polskie drogi emigracyjne. Emigranci polscy na studiach we Francji 1832 1848, Warszawa 1986.

Kuk L., Wielkie zakłady emigracji w latach 1832-1833. Rys historyczno-statystyczny [w:] Rozprawy z dziejów XIX i XX wieku przygotowane dla uczczenia pamięci Profesora Witolda Lukaszewicza, red. S. Kalembka, Torun 1978, s.

Kuzicki J., Duchowni - uczestnicy powstania listopadowego $w$ tzw. wielkich zakładach (dépôts) we Francji w latach 1831-1833 [w:] Wschodnie i zachodnie szlaki migracji Polaków. Ślady działalności kulturalnej, red. P. Kraszewski, M. Lachowicz, T. Nakoneczny, Poznań 2017, s. 46-53.

Kuzicki J., Nieść wiarę i nadzieję na obcej ziemi. Polskie duchowieństwo katolickie w życiu religijnym i polityczno-społecznym Wielkiej Emigracji we Francji (1831-1863), Rzeszów 2014.

Lewak A., Czasy Wielkiej Emigracji [w:] Polska, jej dzieje i kultura, t. III, Warszawa 1934, s.

Micewski B., Semenenko Piotr [w:] Polski Stownik Biograficzny, t. 36, Warszawa-Wrocław-Kraków 1995-1996, s. 220.

Mondonico-Torri C., Les réfugiés en france sous la monarchie de juillet: l'impossible statut, „Revue d'histoire moderne et contemporaine” 2000, no. 47(4), s. 731-745.

Noiriel G., Le creuset français. Histoire de l'immigration, XIXe-XXe siècles, Paris 1988.

Nowak J., Zakłady (dépôts) [w:] Encyklopedia Polskiej Emigracji i Polonii, t. V, red. K. Dopierała, Toruń 2005, s. 376.

Owsińska A., La politique du gouvernement fraçais vis-à-vis des Polonais et de la Question polonaise durant les années 1832-1835 [w:] Pologne. L'Insurrection de 1830-1831, sa réception en Europe, textes réunis par D. Beauvois, Lille-Wrocław 1982, s. 115-119.

Pezda J., Ludzie i pieniądze. Finanse w działalności Adama Jerzego Czartoryskiego i jego obozu na emigracji w latach 1831-1848, Kraków 2003.

Pierre-Henry, Histoire des préfets. Cent cinquante ans d'administration provinciale 1800 1850, Paris 1950.

Réchaussat P., Histoire et légendes de Levroux par..., Chateauroux 1923.

Rederowa D., Polski emigracyjny ośrodek naukowy we Francji w latach 1831-1872, Wrocław-Warszawa-Kraków-Gdańsk 1972.

Sawrymowicz E., O „zakładzie” emigracji polistopadowej w Besançon, „Przegląd Humanistyczny", R. 23, 1979, nr 9, s. 117-126.

Słownik krzemieńczan 1805-1832, wstęp i oprac. W. Piotrowski, Piotrków Trybunalski 2005.

Sokolnicki M., Les origines de l'émigration polonaise en France 1831-1832, Paris 1910. 
Sokołow ska S., Młoda Polska. Z dziejów ugrupowań demokratycznych Wielkiej Emigracji, Wrocław-Warszawa-Kraków-Gdańsk 1972.

Szmyt A., Udziat uczniów i absolwentów Liceum Krzemienieckiego w powstaniu listopadowym [w:] Wokót powstania listopadowego. Zbiór studiów, red. H. Chudzio, J. Pezda, Kraków 2014, s. 207-225.

Tark ow ska E., W drodze do departamentu Côtes-du-Nord, „Meritum” 2016, t. VIII, s. 145166.

Tokarz W., Wojna polsko-rosyjska 1830 i 1831, Warszawa 1993.

Wencel-Kalembkowa U., Działalność gen. Józefa Dwernickiego na emigracji w latach 1832-1848, Warszawa-Poznań-Toruń 1978.

Witkowska A., Cześć i skandale. O emigracyjnym doświadczeniu Polaków, Gdańsk 1997. Zdrada J., Wielka Emigracja po powstaniu listopadowym (seria: Dzieje Narodu i Państwa Polskiego, z. III/46), Warszawa 1987.

Ziółek J., Powstanie listopadowe na Litwie [w:] Powstanie listopadowe 1830-1831, red. W. Zajewski, Warszawa 1990.

Żurawski vel Grajewski R.P., Polskie emigracje 1831-1918 [w:] Historie Polski w XIX wieku, t. IV, red. A. Nowak, Warszawa 2015, s. 121-122. 
